\title{
民家再生における主空間の架構の表現 \\ FRAMEWORK EXPRESSION OF MAIN ROOM IN REFURBISHED TRADITIONAL JAPANESE TIMBER HOUSES
}

\author{
金子晋也*, 西村友樹**, 是永美 樹***, 堀江 亨****,八木幸二***** \\ Shinya KANEKO, Yuki NISHIMURA, Miki KORENAGA, \\ Tooru HORIE and Koji YAGI
}

\begin{abstract}
The aim of this study is to clarify characteristics of refurbished traditional Japanese timber houses, focusing on compositions of frameworks in main rooms after refurbishing. Firstly, shapes of main rooms are analyzed according to three levels of composition; wall, horizontal ceiling and the adjoining relationship to sub-structure, and partitions in main rooms are analyzed too. Secondly, characteristics of frameworks are analyzed with regard to shapes of timber and arrangements of beams. In conclusion, several types of expression in framework arrangement in main rooms are pointed out, and their characteristics are clarified such as the contrast between framework and shape of main room.
\end{abstract}

Keywords : traditional timber houses, refurbishing, framework, expression, main room 民家，架構，再生，表現，主空間

\section{1. 序}

\section{1 研究の背景と目的}

日本の伝統的民豙は、構造部材である架構を見えがかりとしてあ らわすことを意匠的な特徴としてきた。増田一眞は、近代以前の技 術の性格が構造と意匠が一体であったことから「構造即意匠」と言 い、伝統的な木造建築の特徵を示している。また伊藤ていじは、柱 の配列が間取りの形成に方向性を与えるものであるという認識から 「軸組」を「基本構造」と言い、民家にその発展をみている。さらに、 その方向性に実態として把握できる視覚的にまとまりを与えるもの を「造作」としてとらえている。これは、民家の架構が各部屋の性 格と関わりを持ち、空間の形成に影響を与える様子を示すものであ るととらえられる。

一方、近年の資源循環の考えの影響もあり、多くの優れた民家が 保存されている。しかし、保存は現状維持が目的とされるために、 活用する際に現代の生活との機能的な対応が難しい。そこで保存と は別の考えから再生という手法が注目されている。近年では「民家 再生」として設計者の著述も多く、各々の設計概念や空間の特徵に 関して論じられている。

再生に対するアプローチは設計者の判断に委ねられ多様であるが、 既存の架構を有効に利用する点で共通すると考える。なかでも再生 前の民家は全体の架構と床・壁・天井が相互に補完的であるが、架構 の秩序が支配的に空間を統合しているのに対し、再生後は既存の架 構を維持した状態で新たな機能の要求が空間を統合している様子が
みられる。その際に、新たに形成された空間で架構が異なる見えが かりとしてあらわれる点に、民家再生の意匠的な特徵があると考え る。そこで本研究では、再生後の内部空間における形態的な特徵と 架構の見えがかりの対応関係から得られる空間の性格を考察し、民 家再生の意匠的特徴を明らかにすることを目的とする。

\section{2 既往研究}

従来の民家研究は、柱の位置および配列による物理的側面と間取 りの関係に着目することで、地域や年代の比較による特徽を明らか にしてきた。これに対し筆者らは、構法的な視点から梁の架構に着 目した研究を行っており、近年では再生事例を対象とした研究も行 っている。

一方、近年の学術的分野における再生事例を対象にした研究は、 特徵的な事例を対象として環境負荷に対する評価を行ったものや、 改修を前提とした長期借家契約方式から活用のあり方について具体 的事例を通じた検証が行われている。また、民家再生の手法につい て計画学的な側面から、特定の地域の民家再生の動向を調查したも の、特定の設計者を対象に設計手法の特徵を検証したものなどがあ る。また、古材利用の観点から古材の使用箇所や利用形態から空間 構成を検証したものもあるが、本研究のように民家再生における空 間の特徵を架構の構成から意匠的にとらえたものはみられない。

\section{3 研究方法}

再生後の民家は、既存の架構を生かしながら床・壁・天井などの 造作を変化させることによって、伝統的民家とは異なる空間を形成

\footnotetext{
* 東京工業大学大学院理工学研究科 博士課程. 工修

Doctoral Course, Tokyo Institute of Technology, M. Eng.

** 東京工業大学大学院理工学研究科 大学院生・学士 (工学)

*** 東京工業大学大学院理工学研究科 助教. 工博

**** 日本大学生物資源科学部森林資源科学科 准教授·工博 Graduate Student, Tokyo Institute of Technology, B. Eng.

Assistant Prof., Tokyo Institute of Technology, Dr. Eng.

Assoc. Prof., Dept. of Forest Science and Resources, College of Bioresource Sciences, Nihon Univ., Dr. Eng.

Prof., Tokyo Institute of Technology, Dr. Eng.
} 
している。特に居間のように、食堂や台所など複数の機能が隣接す る部屋は、相互の関係を調節する多様な内部空間の展開がみられる。 本研究では、居間を含み架構が連続してみえる空間を主空間とし、 分析を行う（図 1)。

たとえば図 2 の分析例の主空間は、上屋と下屋の異なる構造形式 の境に垂壁があることで、壁面から天井への連続がみられる。また 間仕切りによって整えられた空間に対して、上方にあらわれる架構 の形式は内部空間を統合するものととらえられる。2 章では、以上 のような主空間の形態の特徵を、上屋の平面形、天井の形態および 上屋からみた下屋の隣接関係からとらえ、内部を分割する要素との 関係を検証する。また主空間にあらわれる架構は、真壁における柱・ 梁のような面材に従属するととらえられる部材と、独立柱や飛梁の ように空間内に独立してあらわれるものがある。3 章では架構の組合 せを、空間内に独立してあらわれる架構の部材の種類と配置に着目 し、それぞれの位置関係から検討する。以上の主空間の特徴と架構 の形式の対応関係を整理しその特徵を類型的に把握することで、4 章 では架構からみた民家再生における意匠表現について考察する。

分析対象は、建築家によって提案された民家再生の事例として「住 宅建築」誌に掲載された 42 作品を資料とする (表 1)。

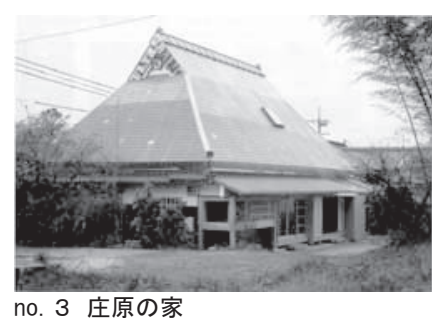

図 1 主空間の位置

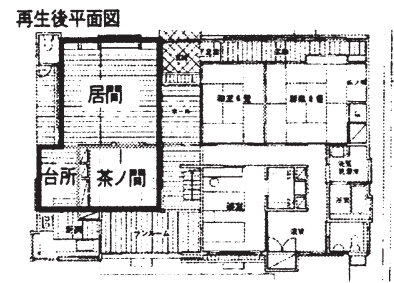
再生前(ドマ) $\rightarrow$ 再生後(機能梅合/有以)

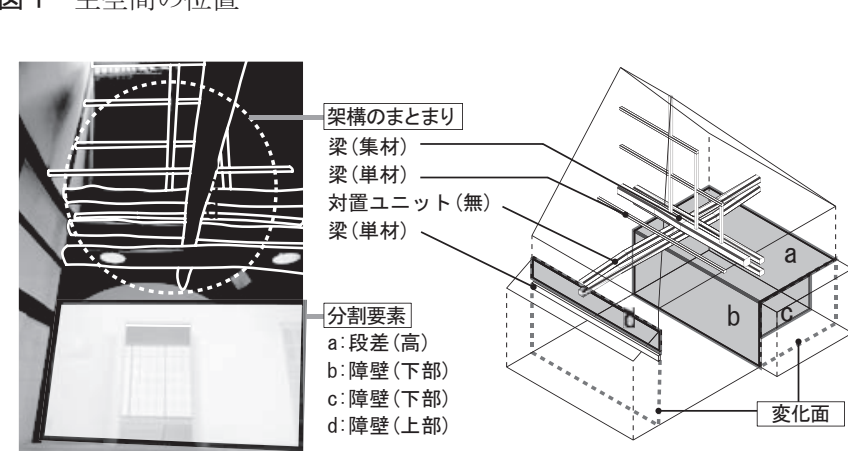

図 2 主空間の分析例 no. 3 庄原の家

\begin{tabular}{|c|c|c|c|c|c|c|c|c|c|}
\hline \multicolumn{10}{|c|}{ 㪼在地 层相形 } \\
\hline 1 & 御津の長屋門 & 矢吹昭良 & 岡山 & 入 & 22 & 八島の家 & 藤岡龍介 & 奈良 & 切 \\
\hline 2 & 矢掛の家 & 矢吹昭良 & 岡山 & 寄 & 23 & 紀寺 ·離れの家 & 藤岡龍介 & 奈良 & 切 \\
\hline 3 & 庄原の家 & 矢吹昭良 & 広島 & 寄 & 24 & 中野邸 & 安藤邦廣 & 茨城 & 寄 \\
\hline 4 & 松江の蔵 & 㞺吹昭食 & 島根 & 切 & 25 & 寺田の家 & 山本良介 & 䈞都 & 切 \\
\hline 5 & 板屋の再生 & 佐藤隆 & 岡山 & $\lambda$ & 26 & 櫻并邸 & 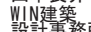 & 京都 & 切 \\
\hline$\frac{6}{7}$ & 曋阿知の家 & 佐藤隆 & 岡山 & $\lambda$ & 27 & 宇都容の民家再生 & 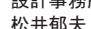 & 阶杤木 & \\
\hline & 英田町の家 & 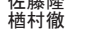 & 岡山 & 入 & 28 & 那須の家 & & 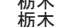 & ג \\
\hline & 内山邸 & 楢村徹 & 岡山 & 入 & 29 & =上荘 & 唱影良孝 & 群馬 & 切 \\
\hline 10 & 英田町の家 & 梄村徹 & 岡山 & 切 & 30 & 池本邸 & 罬谷克司 & 石川 & 切 \\
\hline 11 & 玉島の納屋 & 萩原嘉郎 & 岡山 & $\lambda$ & 31 & M邸 & 降幡廣信 & 群馬 & 寄 \\
\hline 12 & 加須山の納屋 & 萩原嘉郎 & 岡山 & 切 & 32 & 鎌倉の大屋根 & 日影良孝 & 神奈川 & I 切 \\
\hline 13 & 和気 & 大角雄三 & 岡山 & $\lambda$ & 33 & 山中湖の蔵座敷 & 日影良孝 & 山梨 & 切 \\
\hline 14 & & 大角雄三 & 岡山 & 切 & 34 & 朝霞の家 & 鈴禾喜一 & 埼玉 & 切 \\
\hline 15 & 明石 & & 兵庫 & 入 & 35 & 臼杵·小手川家住宅 & 降幡廣信 & 大分 & 切 \\
\hline 16 & 大多羅 & 昭雄 & 岡山 & 寄 & 36 & 焼津 - 曾根家住宅 & 降幡廣信 & 静岡 & 切 \\
\hline 17 & 西植田 & 神家昭雄 & 香川 & 寄 & 37 & - 薮崎家住宅 & 降置廣信 & 千葉 & 寄 \\
\hline 18 & 西大路花屋町の長屋 & 郡裕美 & 京都 & 切 & 38 & 陣場高原の家 & 渡辺彰男 & 東景 & 入 \\
\hline & & & 疠木 & 切 & 39 & 中山邸 & 聟吹昭良 & 岡山 & 入 \\
\hline & & & 零知 & & 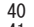 & & & 長野 & \\
\hline & 古門前町の長屋 & 福濱嘉宏 & 東京 & 切 & & 箱根H山荘 & & 神奈川 & I 入 \\
\hline & & & 寄:寄棟 & & 42 & 木曽駒·尚半荘 & 高野康男 & 長野 & 切 \\
\hline
\end{tabular}

\section{2. 主空間の特徵}

前章で述べた分析例のように、主空間は間仕切りなどにより複数 の室に分割されているものが多くみられる。本章では床、壁、天井 により形成される形態と間仕切りなどの位置関係から、主空間の特 徵について考察する。

\section{1 主空間の位置と変化の性格}

民家の多くは、床の有無によって生活部分と土間部分に分けられ ることから、再生前の主空間の位置を床部分（ユカ）と土間部分（ド マ)、または床部分と土間部分両方からなるもの（ユカ十ドマ）によ って分類した。また、再生前の建物が、倉や納屋のように床、土間 の区別がないもの（クラ）は分けてとらえる（表 2)。

次に、柱立ちによって規定される部屋の単位の変化に着目する。 再生前後の主空間における部屋境の変化から「一室維持」、「一室分 離」、複数室連結」、「複数室再構成」の 4 つに分けてとらえ、同時 に再生前の民家にみられる土間境の段差が再生後にみられるものの 有無をとらえる (表 3)。その結果、再生後の主空間は、複数室連結 (20/42) や複数室再構成 $(17 / 42)$ が多く、床面段差無しのものが多 くみられた。このことから、規模の変化がみられるものが多いこと が分かる。

表 2 再生前の主空間の位置

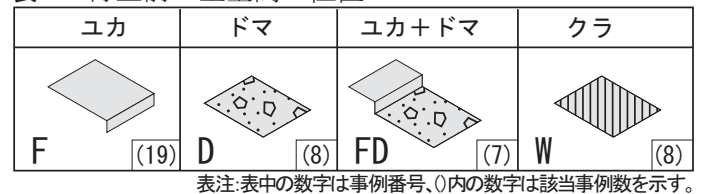

表 3 主空間の変化の性格

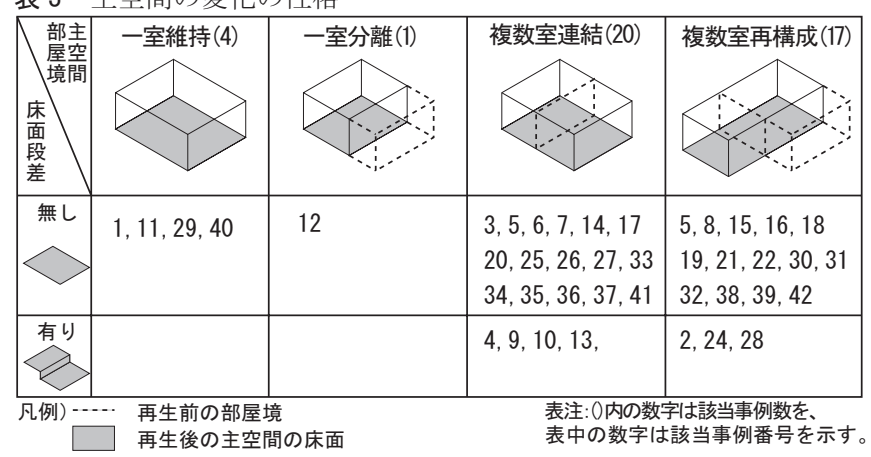

表 4 形態要素の分類
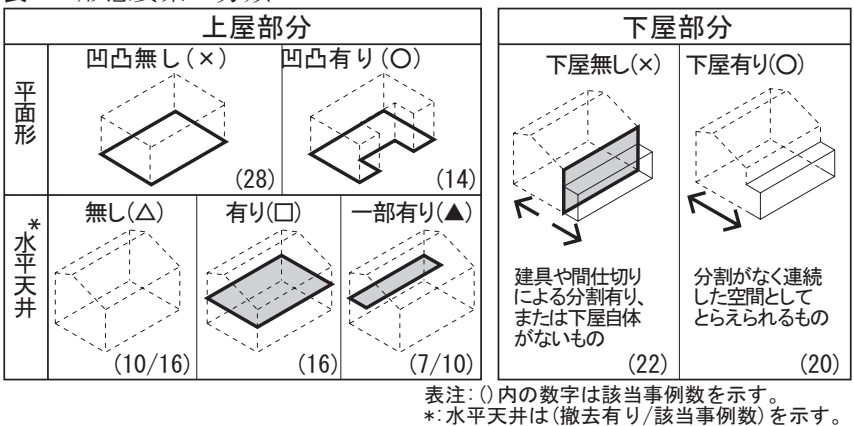

表 5 分割要素の種類

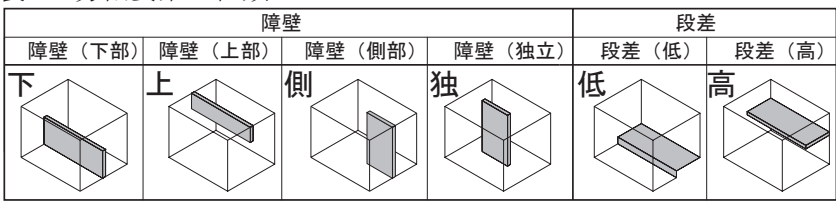




\section{2 主空間の形態要素}

民家の各部屋は、軸組の直交座標に対し、床、壁、天井の造作によ り空間が形成されるととらえられる。そこで、民家の主空間を次の 3 つの水準の形態からとらえる（表 4)。

（1）壁面の取合いからみた平面形（凹凸無し、凹凸有り）

（2）水平天井の有無（無し、有り、一部有り）

（3）連続するする下屋の有無（下屋無し、下屋有り）

水平天井無しおよび水平天井一部有りに関しては、再生前に水平天 井があったものを撤去した事例も合わせて考察する。その結果、水平 天井無し $(10 / 16)$ 、水平天井一部有りと共に多く多くみられた $(7 / 10)$ 。 また、上屋部分の平面形に関しては凹凸無しのものが多く $(28 / 42) 、$

下屋部分は有りのものが約半数みられた $(20 / 42)$ 。

\section{3 形態要素と分割要素の関係}

主空間は、間仕切りや段差のような物理的操作により分割されるこ とで特徴付けられているととらえる。そこで、天井や床の水平方向に 取付くものを障壁（下部、上部）、壁面に取付くものを障壁（側部）、 独立壁を障壁（独立）、スキップやロフトのように断面を分割するも のを段差（低、高）として整理し、分割要素とする（表 5)。

形態要素と分割要素の関係をみると（表 6)、凹凸無しかつ水平天井 無し (9/42)、水平天井有り $(4 / 42)$ のように比較的単純な形態がみられ、 分割要素が独立してみられる。また主空間は、下屋無しで凹凸有りか つ水平天井一部有り $(4 / 42)$ や、下屋有りで凹凸無しかつ水平天井一

表 6 形態要素と分割要素の関係

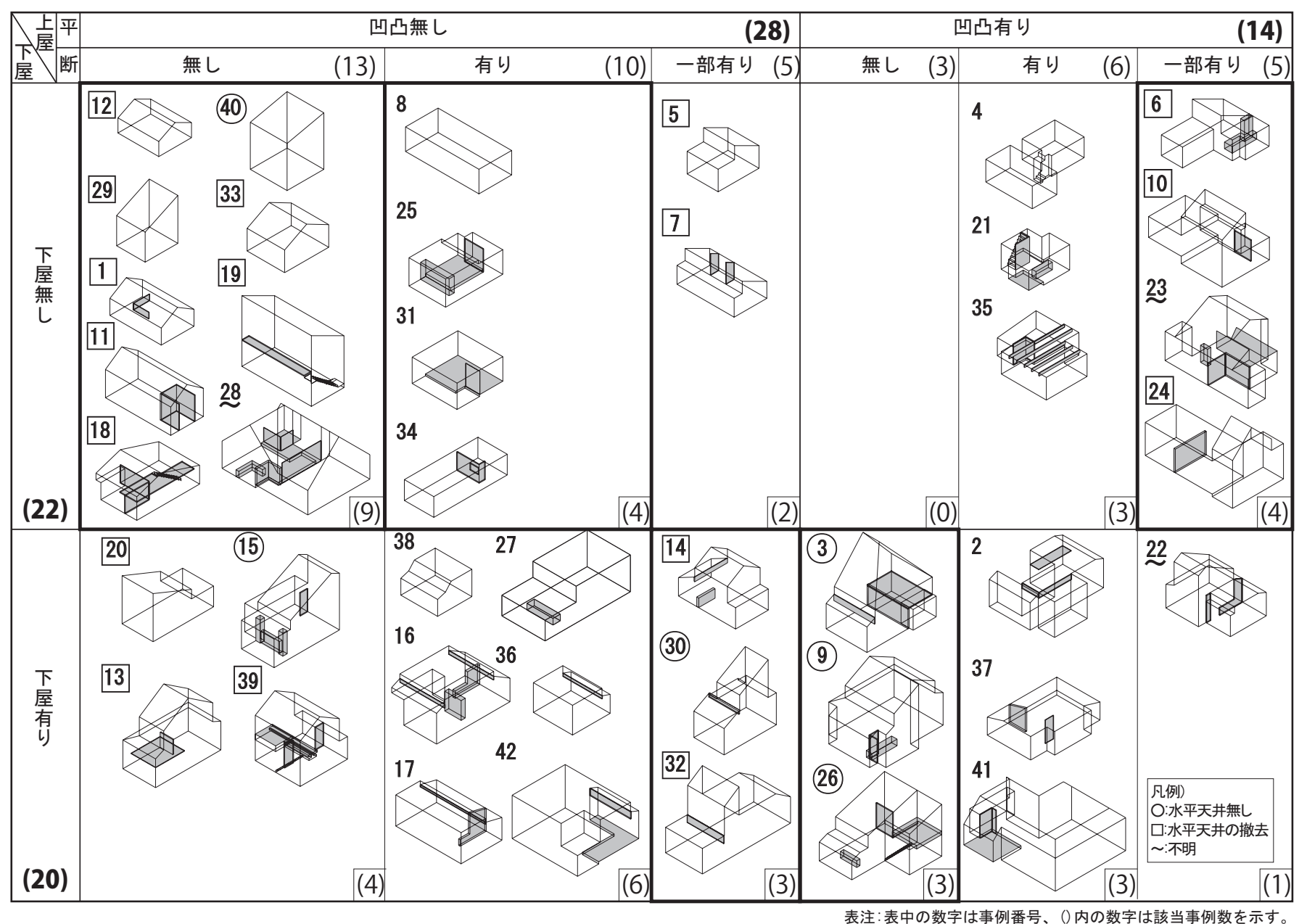

また、国のハッチ部分は分割要素を示す。
部有り（3/42）、凹凸有りかつ水平天井無し（3/42）のように複雑 な形態がみられ、その中に分割要素があるものがみられる。

\section{4 主空間の内部空間の特徵}

ここでは、主空間の形態要素と分割要素を位置関係から把握する。 まず形態要素における平面形の凹凸部、断面の形状が変化する面、 下屋の隣接部の面を変化面として抽出した（表 7)。この変化面と

表 7 変化面の種類

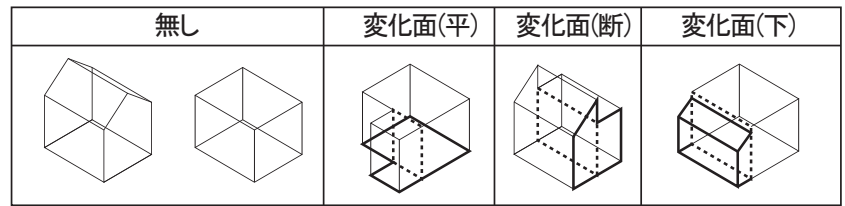

表 8 主空間の分割パタン

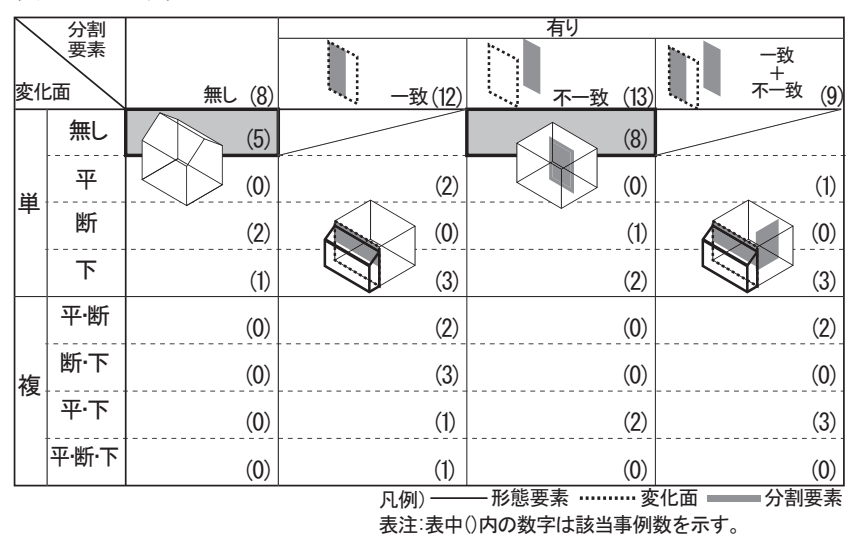


分割要素の位置関係を分割パタンとして一致、不一致、一致十不一 致 (一致と不一致の両方が見られるもの) および無しから検証する (表 8)。

分割要素が一致するもの $(12 / 42)$ は、変化面（下）のもの、変化 面（平）のもの、変化面（断・下）のものなど平面と下屋を含む複数 の変化面を持つものに多いことが分かる。これは、平面や下屋の変 化面と分割要素を一致させることで、内部空間の見えがかりの凹凸 が整えられるものである。

一方で分割要素が不一致のもの（13/42）は、変化面無し (8/13) に多くみられる。これは、内部空間の分割に対して変化の無い形態 によって覆うことで空間のまとまりをつくるものである。

また、一致十不一致のもの $(9 / 42)$ は変化面 (下) のもの、変化面 (平 ・下）のものなどにみられ、これは一致と不一致の特徵を合わせるも のである。また、分割要素が無しのもの（8/42）は、変化面無し (5/8) が多く、その他の事例も変化面（断）や変化面（下）など、主空間 の凹凸が少ない比較的単純な形態のものである。

以上のように再生後の主空間は、変化面と分割要素の位置関係か ら平面や下屋の変化面の凹凸を整えるもの、単純な形態内で分割を 行うもの、比較的単純な形態からなる変化面無しのものがみられた。

\section{3. 架構の種類と組合せ}

民家の架構は、飛梁のように空間内に独立してあらわれるものや、 井桁組のように部材の組合せとして空間内にあらわれるものがある。 そこで、本章では、梁の部材形状とその配置から主空間における架 構を把握する。

\section{1 架構ユニットの種類}

架構の見えがかりの形態を、梁の部材形状とその配置の形式から 特徴を把握する。まず部材形状は、木材の形状がそのまま表される 曲材と、製材された直材がみられる（表 9)。一方、部材のなかでは、 小屋組の形式が和小屋や真束組など、束や貫の複数の部材の集合と してあらわれる場合がある。これらは、見えがかり上は梁と一体的 な形状を形成する部材であるととらえ集材とし、曲材や直材など部 材単体の形状が見えがかりを形成する部材を単材として分ける。

次に、以上の部材が交差や並行など、配置の形式がみられるものを、 架構ユニットとしてとらえる（表 10）。架構ユニットは、一対の部材 が交差する対置ユニットと、部材が並行に連続してあらわれる反復 ユニットに分ける。なかには、格子状を形成するもの（格子ユニッ ト）があり、これは単一の材に反復ユニットが交差するキ型のものと、 反復ユニット同士が交差する井型のものがある。また、ユニットの 形式をとるもの以外に部材が単独であらわれるものもあり、これは 部材（単独）とした。

表 9 部材形状と種類

\begin{tabular}{|c|c|c|c|}
\hline \multicolumn{3}{|c|}{ 梁 } & \multirow[b]{2}{*}{ 柱 } \\
\hline & 材 & 集材 & \\
\hline$S$ & 曲部材 & $p \underset{\text { 束立 }}{p}$ & $\|$ \\
\hline
\end{tabular}

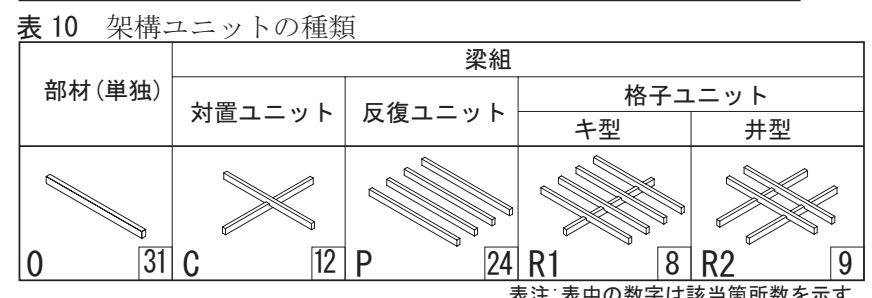

表 11 架構ユニットの複合形式

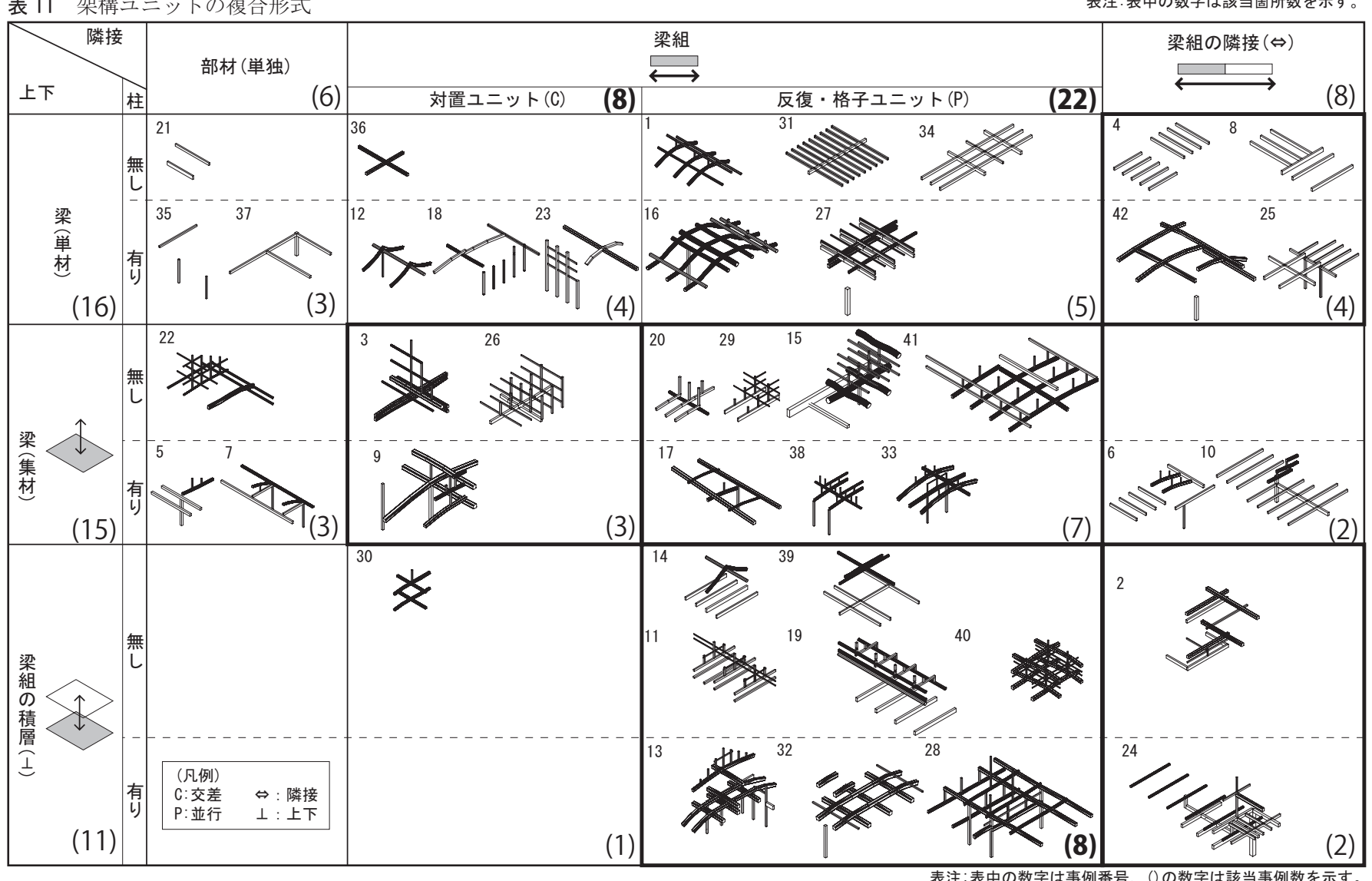




\section{2 架構ユニットの複合}

主空間にあらわれる架構全体の形態は、架構ユニットと部材 (単独) の組合せや、架構ユニット同士の組合せ、部材（単独）同士の組合 せとして異なる単位の複合からとらえる。また、梁組の水平方向の 広がりと、集材などにみる部材の上下の連続性を視覚的特徵として 持つ。そこで、横軸に架構の水平方向の広がりを架構ユニットの形 態および隣接関係からとらえ、縦軸に上下の連続性を部材形状およ び架構ユニットの積層関係からとらえる（表 11）。また、部材形状で は柱の有無を同時にみた。

その結果、事例の多くで対置ユニット $(8 / 42)$ や反復・格子ユニ ットがあらわれ (22/42)、形態的にまとまりのある架構ユニットを 選択していることが分かる。一方、部材（単独）であらわれるもの は全体的に少ないが $(6 / 42) 、$ 柱のあらわれるものや集材があらわれ るものなど、架構の接続関係があるのもみられた。上下の連続性は、 部材が集材のもの (15/42) や架構ユニットが積層してみえるもの (11/42) などがみられ、なかでも積層するものの多くが低い位置で 反復・格子ユニットを持ち水平方向の広がりがある形態を選択して いる（8/11）。また、対置ユニットが集材をともなうもの（3/42）の ように、立体的な構成がみられた。梁組の隣接は単材のものが多く (4/8)、類似した架構ユニットが組み合わさることで水平方向の広が りを持つものがみられた。さらに、梁組の積層かつ隣接のもののよ うに架構ユニットが主空間内で複合するものがみられた（2/42）。

\section{4. 主空間の架構の表現}

前章までは、分割パタンからみた主空間の特徵と、架構の配置か らみた架構ユニットの複合を個別に検討してきた。ここでは、これ らの結果をもとに、両者の関係として主空間の性格をとらえ、空間 内に位置付けられることにより生じる架構の表現について考察する。

\section{1 主空間の形態と架構の対応関係}

ここでは架構が主空間に架かる範囲を、2 章で得た変化面との関係 からとらえ、その特徴を把握する。主空間内に架構が全体にあらわ れるもののうち、多くは主空間において一体的なまとまりとしてと らえられる。なかでも、変化面内に架構が納まるもの（a）が多く、 変化面を越えてあらわれる架構を持つもの（a'）もみられた。

また、変化面上に架構ユニットを形成しない単材として架かるも の (b)、架構ユニットの単位が変化面で切り替わるもの (c) もみら れた（表 12）。a と a’ は架構の形態によって空間にまとまりを与え るものとして一体型としてとらえる。 b は分割要素と同様に空間の分 割を明確化するものとして境界型ととらえ、 $\mathrm{c}$ は異なる架構ユニット がみられる併置型ととらえる。

\section{2 分割パタンと架構ユニットからみた主空間の性格}

前節で得られた民家再生の主空間における架構のあらわれ方に対 して、前章までに得た分割パタンと架構ユニットの複合形式の関係、

表 12 架構と主空間の対応関係

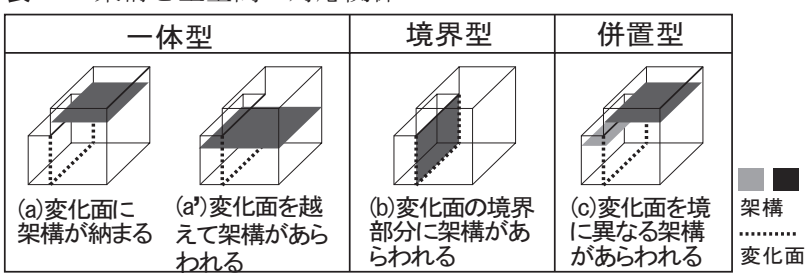

および対応する天井面の形態を検証する（表 13）。その結果、主空間 についていくつかの特徴的な性格がみられた。

類型 A、B、C、D は架構と主空間の対応関係が一体型 (a) (a’) である。 類型 $\mathrm{A}$ は分割パタンがなしであり、主空間が一体的な視覚的まとま りととらえられるものである。また、架構ユニットが集材によって 上下の連続性を持つものかつ水平天井無しであり、架構の立体的な あらわれ方が特徴的なものである。類型 B は分割パタンが不一致で あり、分割された視覚的まとまりに対し架構ユニットが横断してあ らわれることにより、主空間が一体的にとらえられるものである。 B1 は反復・格子ユニットが水平方向に広がりを持ち架構ユニット同士 が積層かつ水平天井無しであり、主空間が低い位置の架構ユニット を境に分離されるものといえる。B2 は格子ユニットが水平方向の広 がりを持ち、かつ水平天井有りであり、主空間の形態と架構の線材 が同調的な性格を持つといえる。類型 C は分割パタンが一致であり、 複数の視覚的まとまりからとらえられる一部に架構ユニットがあら われることにより、主空間が一体的な部分とそれに付属的な部分と してとらえられるものである。C1 はユニット同士の積層かつ水平天 井一部有りであり、積層する架構により生じる上下に質の異なる空 間が際立つものといえる。C2 は変化面内に架構ユニットが納まるも のかつ水平天井有りであり、架構ユニットの組合せが象徴的にあら われるものといえる。類型 D は分割パタンが不一致と一致を併せ持 ち、Bと $\mathrm{C}$ の性格を持つ複合的な視覚的まとまりを持つものである。 D1 は対置ユニットと集材による上下の連続性を持つものかつ水平天 井無しであり、対置する架構が主空間に象徴的にあらわれるものと いえる。D2 は反復・格子ユニットまたは類似した架構ユニットの隣接 が水平方向の広がりを持ち、かつ水平天井有りであり、架構の水平 的な連続性が主空間全体を横断し、架構の組合せによる主空間の統 合がみられるものである。

類型 $\mathrm{E}$ は架構の対応関係が境界型（b）のもので、部分的な架構の あらわれが、空間の変化面と一致することで境界部を強調するもの ととらえられる。E1 は変化面に単材のみあらわれるものかつ水平天 井有り、E2 は変化面に単材があらわれ変化面内に集材が納まるもの かつ水平天井一部有りである。なかでも $\mathrm{E} 2$ は架構ユニットのような 形態的まとまりとしての特徵はみられないが、部分的な吹抜けに架 構の一部をあらわすことで、再生によって形成された空間形態と架 構のまとまりとのずれを際立たせてみせるものといえる。

F は対応関係が併置型（c）で、変化面を境に異なる架構ユニット がみられるもの、かつ水平天井一部有りのものであり、多方向へ広 がる空間の形態と架構の広がりが対応したものといえる。

以上のように民家再生における主空間の性格を、分割パタンと架 構ユニットの関係によって示した。

\section{3 各類型と水平天井の撤去の関係}

前節で得られた主空間の類型について、天井の形態が水平天井無 しおよび水平天井一部有りのものを小屋裏までいたる立体的な主空 間、水平天井有りのものを水平天井で整えられた主空間として整理 し、2 章で得た水平天井の撤去を合わせて検討し、再生後の架構の見 えがかりの特徴について検証する（表 14）。

まず、水平天井が撤去された $\mathrm{A} 、 \mathrm{~B} 1 、 \mathrm{C} 1 、 \mathrm{E} 2 、 \mathrm{~F}$ は、吹抜け空間に 架構が特徴的にあらわれるものである。なかでも、再生後に水平天 井を撤去し、新たに 主空間全体を吹抜けとしたものとしてA（3/4）、 
B1（5/6）がある。A は、吹抜けに立体的な架構のあらわれが位置す ることで、再生後の空間に象徵的な空間をつくりだすのに対し、B1 は吹抜けに上方向の段階性が架構の積層により付加されている。

また、C1 (2/3)、E2（2/3)、F（3/3）は、主空間内で部分的に吹 抜け空間を持つことから、高い空間と低い空間の対比がみられる。 特に $\mathrm{C} 1$ のように主空間が分割されるものは、視覚的まとまりによる 一体的な空間と付属的な空間の対比がこれに重なることで、再生に よって架構の配置が強調されている。さらにFのように架構が隣接
することによって多方向に広がるものは、水平天井を部分的に撤去 することで、再生後に多方向の連続性を持つ内部空間が展開してい るといえる。

一方、再生前から小屋裏までいたる立体的な主空間、つまり小屋 をあらわしていた D1 は、交差する架構の象徵的なあらわれと間仕切 りなどによる内部空間の構成が対比的にとらえられるものである。 これは、再生前と架構が異なる見えがかりとなる点から、民家の架 構と主空間の意匠的な対峙が明快にあらわれるものといえる。

表 13 分割パタンと架構ユニットからみた主空間の性格

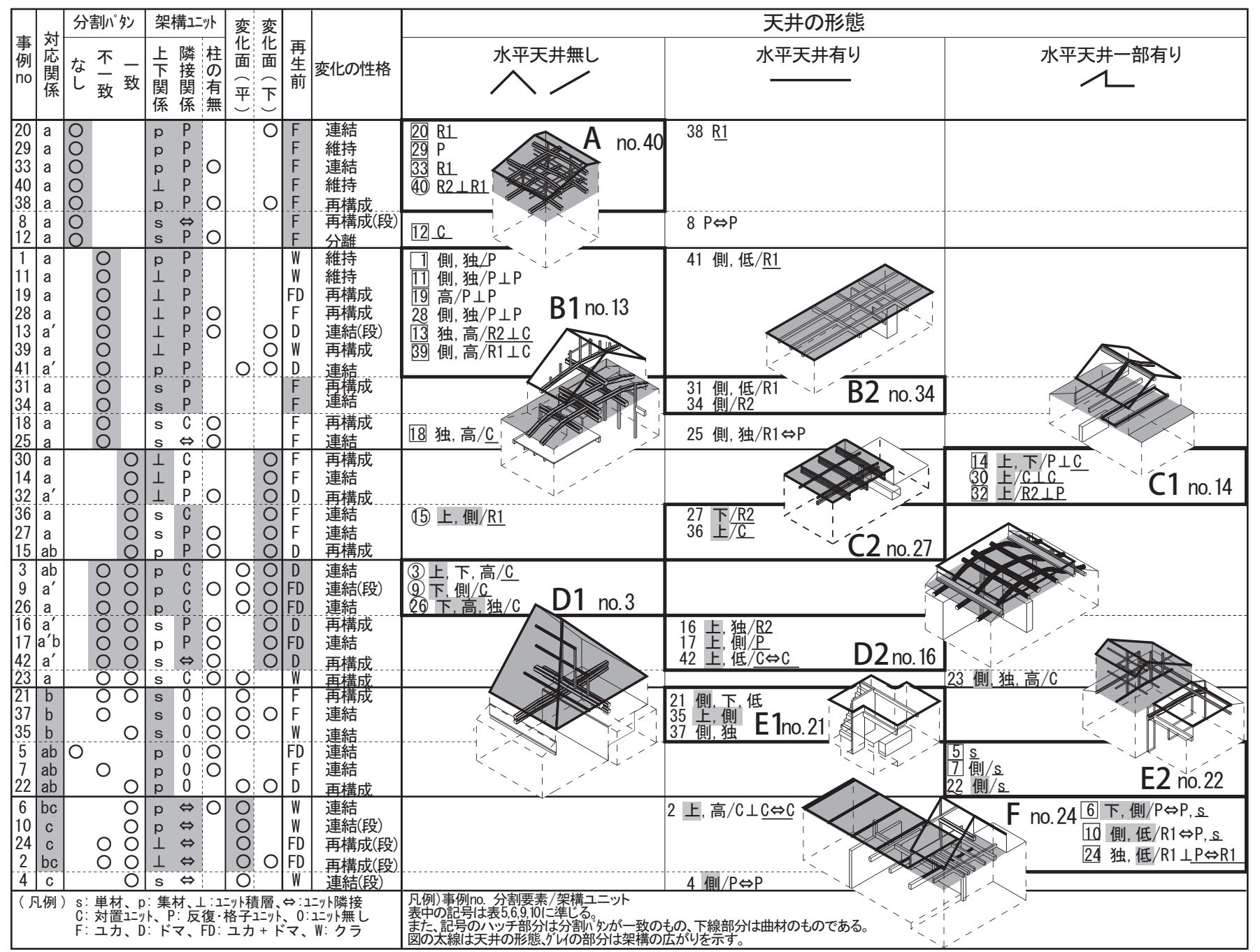

表 14 各類型と水平天井の撤去の関係

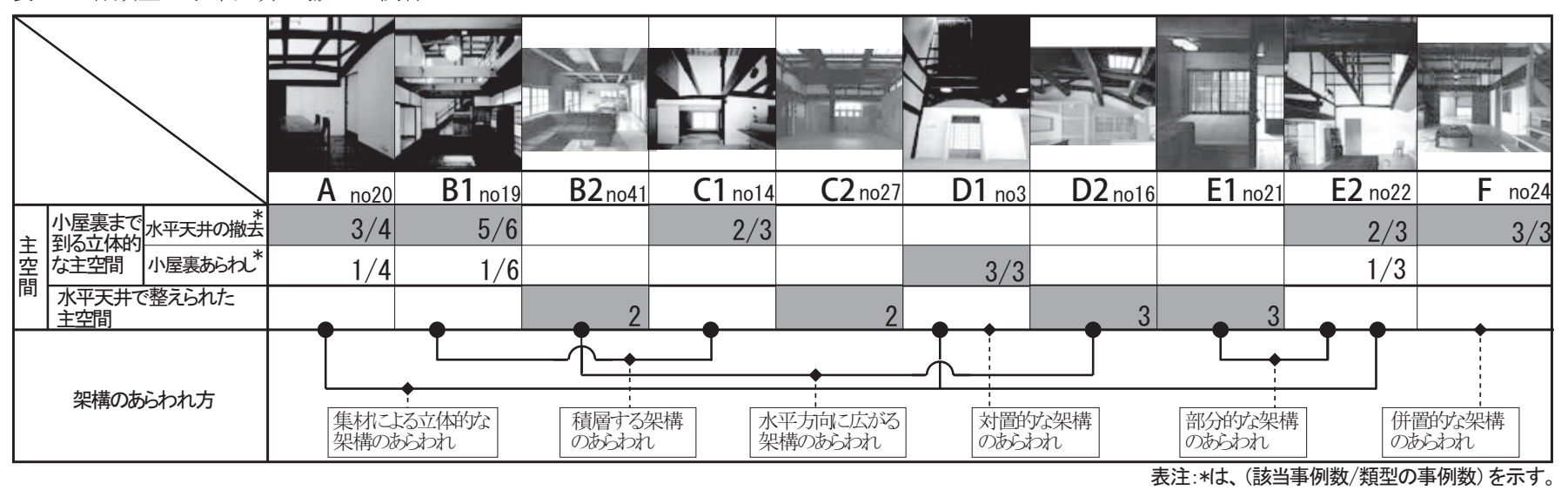




\section{5. 結}

本研究では、民家再生における居間を中心とした主空間を対象と して、内部空間の分割と架構の形式をそれぞれ検討した。

内部空間は、比較的単純な形態内を障壁や段差で分割するものや、 平面形の凹凸や下屋の隣接部分に分割要素を一致させることで空間 を形成しており、多様な展開がみられた。また、架構の形式は、部 材の交差や並行といった見えがかりのまとまりを架構ユニットとし て整理することで、水平方向の架構の広がりと上下の連続性を把握 した。多くの事例で反復・格子ユニットがみられ、再生時には架構 のまとまりを選択する傾向がみられた。

さらに、主空間における架構の対応関係と、内部空間の分割、架 構の形式を類型的に把握した。その結果、主空間における架構のあ らわれ方を整理し、象徵的にとらえられるものや連続性により空間 を統合するものなどの特徴を明らかにした。また、再生後の水平天 井の撤去から、主空間における架構の特徵付けや造作や障壁との対 比による強調、多方向の連続性の展開のあり方など、架構が内部空 間の形態との関係から表現として位置付けられることを示した。こ れは、民家再生の意匠における、民家の構成原理と現代的な空間の 対応関係のあり方についての一端を示すものであると考えられる。 本研究は主空間に限定して考察を行ったが、今後は他の諸室を含む 民家全体の表現についても明らかにする予定である。

注

注 1) 本研究では、参考文献 1 を参考化構法的な視点から近代以前の技術に着 目し、民家を伝統的民家と呼んでいる。事例は戦前までに建築されたもの を対象としている。また、特筆しない限り本研究ではこれ以降、伝統的民 家を単に民家と記述している。

注 2）従来も民家は、動線空間や水回り空間など機能的な更新が増改築によっ てなされてきたが、増改築の行われた民家は、既存の床·壁·天井等の造作 を保持した状態で機能的な付加を行うため大幅な用途変化は見られないと 考え、民家再生と異なる手法としてとらえる。

注 3）「住宅建築」誌のうち 1975 年から 2006 年 9 月（特集号含む）までに民 家再生を取り上げたもので、平面や断面など資料が充分であった 42 作品 を対象としている。

注 4) 例えば伊藤ていじは、著書 (参考文献 2) の中で民家の構成のうち骨組 をフレーム・ワーク、造作をフィックスチャー、特に各室をつくりだすも のをインテリア・フィックスチャーと定義し、骨組の段階の不確定な空間 の方向付けをするものが造作であると説明している。

\section{参考文献}

1）増田一眞 : 建築構法の変革, 建築資料研究社, pp. $121 \sim 122,1998$

2) 伊藤ていじ：日本デザイン論，鹿島出版会，pp. $91 〜 92,1966$

3）降幡廣信 : 民家再生の設計手法, 彰国社, 1997

4) 安藤邦廣 : 住まいを四寸角で考える, 学芸出版社, 2005

5）古民家再生工房：古民家再生術, 住まいの図書出版局, 1995

6）吉田靖：日本における近世民家（農家）系統的発展，奈良国立文化財研究 所, 1985

7）堀江亨, 茶谷正洋，八木幸二：「さしものづくり」における架構と空間構成 の変化過程 : 石川県鹿西町周辺の木造住宅における架構法の継承に関する 研究 その 1 , 日本建築学会計画系論文報告集 No. 432, pp. $61 \sim 68,1992.2$

8）堀江亨：古民家の再生による架構と空間構成の変容について：合体再生事 例における検討，日本建築学会大会学術講演梗概集（東北），pp. $703 〜$ 704,2000

9）橋本征二，松尾好恵，藤岡龍介：民家の再生による環境負荷・コストの削
減効果とその簡易予測，日本建築学会計画系論文報告集 No. 549, pp. 59 〜 $65,2001.11$

10）中園眞人, 大内裕子 , 山本幸子 : 改修を前提とした長期借家契約方式と改 修計画策定手順の提案： 定期借家方式による民家再生システムに関する研 究, 日本建築学会計画系論文報告集 No. 594, pp. $147 \sim 154,2005.8$

11）西田和美，小笠原香代：民家再生に関する視点と動向，日本建築学会大会 学術講演梗概集（東北），pp. $585 \sim 586,2000$

12）飯島誠之, 富岡義人：降幡廣信の民家再生の手法に関寸る研究, 伝統的 間取りの現代的転換を主軸として, 日本建築学会大会学術講演梗概集 (関東) pp. $773 \sim 774,2006$

13）成瀬曜子 : 古材の活用形態と空間価值, 関東学院大学修士論文, 2005

14）上村克朗, 小西敏正他 : 建築構法表現に関する研究, 日本建築学会大会学 術講演梗概集（北海道），pp. $578 \sim 568 ， 1986$

15) 大河直躬 : 本棟造と現代建築, 住宅建築, 建築資料研究社, pp. $6 \sim 7$ 1983. 9

16) 川島宙次 : 滅びゆく民家 間取り・構造·内部，主婦と生活社，1973

（2007年 7 月 10 日原稿受理，2007年12月28日採用決定） 